\title{
Iron-Selective Electrode Based on Phosphorylated Calix-6-Arene Derivative
}

\author{
Mohsen M. Zareh"1,2*, Wael Zordek', Ahmed Abd-Alhady ${ }^{1}$ \\ ${ }^{1}$ Department of Chemistry, Faculty of Science, Zagazig University, Zagazig, Egypt \\ ${ }^{2}$ Department of Chemistry, Faculty of Science, Tabuk University, Tabuk, Saudi Arabia \\ Email: "mohsenzareh@hotmail.com, ${ }^{*}$ mmzareh@ut.edu.sa, ${ }^{*}$ mmzareh@zu.edu.eg
}

Received 24 October 2014; revised 24 November 2014; accepted 23 December 2014

Copyright (c) 2014 by authors and Scientific Research Publishing Inc.

This work is licensed under the Creative Commons Attribution International License (CC BY).

http://creativecommons.org/licenses/by/4.0/

(c) (i) Open Access

\begin{abstract}
The construction and performance characteristics of a novel Iron(III) membrane sensor based on (37-bis-[(diethoxy-thiophosphoryl)-oxy]-5,11,17,23,29,35-hexa-kis-(1,1-dimethylethyl)-calix[6]arene-38,39,40,41,42-pentol) (A) were reported in this paper. The sensor was prepared by incorporating compound $(A)$ into a plasticized polyvinyl chloride PVC membrane. The electrode reveals a Nernstian behavior over a wide iron ion concentration range $\left(1.0 \times 10^{-2}-1.0 \times 10^{-4} \mathrm{~mol} \cdot \mathrm{L}^{-1}\right)$, and relatively low detection limit $\left(1.0 \times 10^{-5} \mathrm{~mol} \cdot \mathrm{L}^{-1}\right)$. The potentiometric response was independent on the $\mathrm{pH}$ of the solution in the range of $4-7$. The electrode showed a very short response time $\{<5$ s). It exhibited very good selectivity relative to a wide variety of metal cations. Correlation of selectivity coefficient values with ionic radii of interferent cations was discussed. The proposed ironISE was applied for analysis of iron containing samples with comparison to a recommended spectrophotometric method.
\end{abstract}

\section{Keywords}

Ferric Ion Determination, Ion Selective Electrode (ISE), PVC-Membrane

\section{Introduction}

Different ionophores were used for preparing iron ion-selective electrodes. Benzilthiocarbohydrazide [1] and $\mathrm{N}$-(2-hydroxyethyl) ethylenediamine-N,N',N"-triacetic acid [2] were used as sensor materials for preparing a PVC (polyvinyl chloride) membrane ferric ISE by Zamani et al. They only worked up to $\mathrm{pH} 4.5$, although they had very sensitive linear ranges $\left(10^{-2}-10^{-7}\right.$ and $\left.10^{-2}-10^{-9} \mathrm{M}\right)$. Both electrodes had a life time of more than 10 weeks. Zareh et al. [3] used 1-pyrrolidine dicarbothioate for preparing Fe-ISE for the determination of iron in lubrication oil. This electrode showed trivalent Nernstian slope at concentration range $10^{-5}-10^{-1} \mathrm{M}$. Benzo-

*Corresponding author. 
18-crown-6 was applied as the sensor material for an Iron(III) ion selective electrode by Ekmekci et al. [4]. The slope of that electrode was monovalent slope ( $57 \mathrm{mV} /$ decade). The electrode was responding to $\mathrm{FeCl}_{4}^{-}$as an anion electrode. It had a life time up to 2 months. An Iron(III) ion-selective based on a $\mu$-bis-(tridentate) ligand (2-phenyl-1,3-bis [3'-aza-4'-(2'-hydroxyphenyl)-prop-4-en-1'-yl]-1,3-imidazolidine) was constructed by Gupta et al. [5]. It had a working $\mathrm{pH}$ range 3.5 - 5.5. The age of this electrode was 2 months. Sil et al. [6] prepared a coated-wire iron (III) ion-selective electrode based on iron complex of 1,4,8,11-tetraazacyclotetradecane. The slope of that electrode was monovalent ( $60 \pm 5 \mathrm{mV} /$ decade), with a $\mathrm{pH}$ working range 1.5 - 3.5. A novel ion selective potentiometric sensor for direct determination of $\mathrm{Fe}(\mathrm{III})$ in the presence of $\mathrm{Fe}(\mathrm{II})$ was constructed by Mashhadizadeh et al. [7]. It was based on 2-[(2-hydroxy-1-propenyl-buta-1,3-dienylimino)-methyl]-4-p-tolylazophenol as a neutral carrier. It showed a super-Nernstian behavior ( $28.5 \mathrm{mV} /$ decade) for at least 2 months. It works within $\mathrm{pH}$ range 4.5 - 6.5. Mahmoud [8] applied iron ion-selective electrodes for direct potentiometry and potentiotitrimetry in pharmaceuticals. The electrode was based on ion association complexes of Iron(II) 2,4,6-tri (2-pyridyl)-1,3,5-triazine with tetraphenylborate or phosphotungstic acid. In addition, plasticized carboxylated PVC was applied for this membrane. It worked within a pH range $3.2-7.1$ and a life time of 3 months. Ribonucleic acid as a novel ionophore for potentiometric membrane sensors of some transition metal ions was used by Hassan et al. [9]. It showed a Nernstian behavior toward $\mathrm{Fe}^{2+}$ (35.5 mV/decade) over a $\mathrm{pH}$ range 4.0 - 6.5 (for $10^{-6}-10^{-2} \mathrm{M}$ ). Ferroin-TPB was applied as a membrane sensor for the potentiometric determination of either $\mathrm{Fe}^{2+}$ or $\mathrm{Fe}^{3+}$ ion by Hassan and Marzouk [10]. This type of sensor was based on responding to the charged ion complex "ferrion". It behaved like a cationic divalent electrode (30 mV/decade). It showed a $\mathrm{pH}$ range 3 - 9 down to $4 \times 10^{-7} \mathrm{M}$ ferrion.

The present iron electrodes were constructed depending on the use of (37-bis-[(diethoxy-thiophosphoryl)oxy]-5,11,17,23,29,35-hexa-kis-(1,1-dimethylethyl)-calix[6]arene-38,39,40,41,42-pentol) (A), “Figure 1". Here, the study is elaborated for studying the effect of ionic radii of interferent cations to their selectivity coefficient values towards ferric ion. The application of this electrode facilitates the measurement and analysis of ferric ion in different samples. None of the previous work suggested the use of calix-6-arene for iron determination.

\section{Experimental}

\subsection{Reagents and Material}

37-bis-[(diethoxy-thiophosphoryl)oxy]-5,11,17,23,29,35-hexakis(1,1-dimethyl-ethyl)-calix[6]arene-38,39,40,41, 42-pentol (A) synthesized according to a previous procedure (kindly provided by Prof. Z. Bozoka, Warsaw Techical Univ., Poland) [11], and tetra-p-chlorophenylborate (B) [Fluka] were the main ionophores for preparing the applied membranes. The used plasticizers were dioctylsebacate (DOS) [Aldrich], nitrophenyloctylether (NPOE) [Fluka]. Polyvinylchloride (PVC) [Fluka] was the membrane matrix. The membrane components were dissolved in tetrahydrofuran (THF) [Fluka]. A (0.1 M) standard stock solutions of ferric cholride [Aldrich] was prepared and dilutions were made to cover the required range $\left(10^{-2}-10^{-7} \mathrm{M}\right)$. To perform the selectivity studies, the analytical reagent grade of nitrates of $\mathrm{Na}^{+}, \mathrm{K}^{+}, \mathrm{NH}^{4+}, \mathrm{Ag}^{+}, \mathrm{Ni}^{2+}, \mathrm{Hg}^{2+}, \mathrm{Cu}^{2+}, \mathrm{Zn}^{2+}, \mathrm{Co}^{2+}, \mathrm{Cd}^{2+}, \mathrm{Pb}^{2+}, \mathrm{Sr}^{2+}$, $\mathrm{Mg}^{2+}, \mathrm{Ca}^{2+}$ and $\mathrm{Al}^{3+}$ were used. Diluted solutions $\left(10^{-2}-10^{-4} \mathrm{M}\right)$ were obtained by careful dilution of the standard

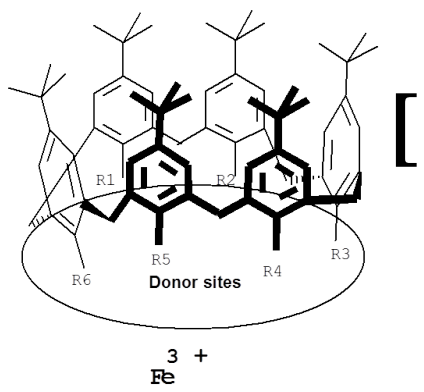

(A)

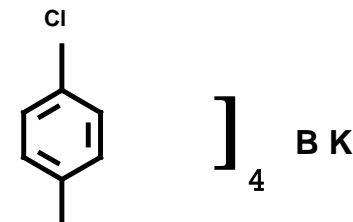

Potassium tetra[p-chlorophenyl] borate (KTpCIPB)

(B)

Figure 1. Structural formulas of: (A) 37-bis-[(diethoxy-thiophosphoryl)oxy]-5, 11,17,23,29,35-hexa-kis-(1,1-dimethylethyl)-calix[6]arene-38,39,40,41,42-pentol; (B) potassium tetrakis-[3,5-bis-(trifloro-methyl)-phenyl] borate. 
stock solution. Double distilled water was used throughout.

\subsection{Equipment}

The potentiometric/pH-measurements were carried out (at $25^{\circ} \mathrm{C} \pm 1{ }^{\circ} \mathrm{C}$ ) on a digital research pH-meter (Jenway, UK) (sensitivity, $\pm 0.1 \mathrm{mV}$ ) coupled with a channel selector. The spectrophotometeric measurements were carried using (UV1800-Schimadzu-Japan).

\subsection{Electrode Preparation}

The measurement was carried using an electrode, which was assembled using Teflon tube (length $=10 \mathrm{~cm}$, diameter $=4 \mathrm{~mm}$ ) fitted with PVC-tube end. Three membrane compositions (I-III) were tried $1 \% \mathrm{w} / \mathrm{w}$ ionophore (either A or B); 33\% w/w PVC and 66\% w/w solvent mediators (NPOE) or (DOS). These components were dissolved in THF and poured into glass rings of $4 \mathrm{~cm}$ i.d. resting on a glass plate. The mixture was left overnight for evaporation, and then the resulting membrane was cut into discs of $6 \mathrm{~mm}$ i.d. Each disc was fixed to the end of PVC-tube at the end of the electrode. The electrode-compartment was filled with an aqueous inner filling solution (0.01 M ferric nitrate and $\mathrm{KCl}$ ) IF. "Table 1", showed the composition of membranes used for preparing the iron-ISE. For electrode conditioning, it was soaked for $24 \mathrm{~h}$ into $1 \times 10^{-2} \mathrm{M}$ solution of $\mathrm{Fe}^{3+}$ before use.

\subsection{Potentiometric Measurements}

$25 \mathrm{ml}$ aliquots of $\mathrm{Fe}^{3+}$ solution $\left(10^{-7}-10^{-1} \mathrm{M}\right)$ were transferred to $50 \mathrm{ml}$ beakers in presence of $0.1 \mathrm{M} \mathrm{KNO}_{3}$ for ionic strength adjustment and buffered at pH5 using acetate-buffer solution. The ferric-ISE was dipped into the solution in conjunction with Ag-AgCl double junction reference electrode (Orion model 900200). The cell potential was recorded corresponding to each $\mathrm{Fe}^{3+}$-concentration. A calibration graph can be constructed for the cell potential versus $-\log \left(\mathrm{Fe}^{3+}\right)$. The following cell assembly was applied:

$$
\text { Ag-AgCl reference||sample solution||membrane|inner filling|Ag-AgCl. }
$$

The potentiometric selectivity coefficient $\left(\mathrm{K}_{\mathrm{Fe}^{3+}, \mathrm{X}^{\mathrm{Z}}}^{\mathrm{P}}\right.$ ) values for different common cations were determined by the separate solution method [12] ( $10^{-3} \mathrm{M}$ solutions for both iron and interferent). The $\mathrm{pH}$-effect on the potential of the proposed electrode was studied by recording the potential after adjusting the $\mathrm{pH}$ of tested solutions using $0.1 \mathrm{M} \mathrm{KOH}$ or $0.1 \mathrm{M} \mathrm{HCl}$.

\subsection{Determination of Iron in Its Samples Using ISE-Fe ${ }^{3+}$}

Different iron-containing samples were prepared. The standard addition method was used for analysing these samples by using the proposed electrode. The samples were previously treated with $\mathrm{HCl}$ to referee the complexed iron. The method based on addition of known standard $(0.558 \mathrm{ppm})$ to the unknown samples. Then the $\mathrm{mV}$-measurements were conducted by the proposed iron selective electrode. The obtained readings were compared to previously prepared calibration graph covering the measured concentration range (0.5618 - $0.926 \mathrm{ppm})$.

For evaluation of the proposed electrode and the accuracy, results from another recommended method was conducted. The samples were analysed by spectrophotometric method [13] for comparison. The procedure was

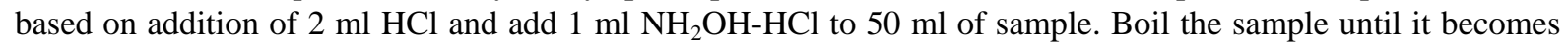
15 - $20 \mathrm{ml}$ then cool. Transfer the solution to a volumetric flask. Add $10 \mathrm{ml}$ amm. acetate and $4 \mathrm{ml}$ 1,10-phenanthroline to the exit solution and complete to $50 \mathrm{ml}$ with distilled water. Wait $10 \mathrm{~min}$. until the color appears. Then, the samples were measured by using spectrophotometer.

Table 1. Composition of membranes I, II and III used for preparing ion selective electrode for Iron(III).

\begin{tabular}{|c|c|c|c|c|c|c|c|}
\hline Composition, w/w\% & PVC & DTPCX & TpClPB & DOS & NPOE & \% ionophore & Slope, $\mathrm{mV} /$ decade \\
\hline I-membrane & 60 & 1 & 1.2 & 0 & 120 & 1.206 & 48 \\
\hline II-membrane & 60 & 1.4 & 1.6 & 121 & 0 & 1.630 & 32 \\
\hline III-membrane & 61.2 & 2.7 & 0 & 0 & 121.8 & 1.475 & 22 \\
\hline
\end{tabular}




\section{Results and Discussion}

\subsection{Effect of Composition}

Different membrane compositions were prepared for optimization of the best one. Electrodes I and II comprised the membrane with NPOE plasticizer, while electrode-III comprised membrane with DOS as plasticizer. Compound (B) was a charged additive for the sensor material of electrodes I and II, while (B) was the only main ionophore for III.

By comparing the electrodes I and II, after 1 day soaking, the slope of type I was $59 \mathrm{mV} /$ decade, while for type II it was $15 \mathrm{mV} /$ decade. This is because both electrodes had different plasticizers (NPOE and DOS), which played an important role in the electrode response [14]. "Figure 2" shows calibration graphs for the three membrane types. It can be reported that NPOE had an active exchange site that works as an ionophoric group. For electrode type I both B and NPOE played a role in the electrode behavior. Double effect resulted in the high value of the slope $59 \mathrm{mV} /$ decade, but when only TpClB was present the slope decreased $50 \%$ reaching 30 $\mathrm{mV} /$ decade.

After 6 days, the slope values for electrodes (types I and III) with NPOE decreased, while it increased for electrode II. The decrease in slope values for I and II is due to usual leaching out of membrane components. For membrane II, the increase in slope can be attributed to the slow interaction between $\mathrm{Fe}^{3+}$ and membrane ionophore as a result of the presence of DOS.

After prolonged soaking (2 months) electrode I lost the monovalent response, electrode II lost the divalent response, while electrode III reserved its trivalent response.

The detection limit (DL) of an ISE can be defined as the cross point of lines segments fitted to linear segments of emf vs $\log a_{\mathrm{F}^{3+}}$ [12]. For membrane-III, the recorded DL was $1.2 \times 10^{-5} \mathrm{M}$ after 1 day soaking time. It reached $3.9 \times 10^{-6} \mathrm{M}$ after 2 months. The DL reached $6.3 \times 10^{-7}$ for electrode I after 42 days continuous soaking. "Table 2", shows the obtained results.

Mechanism of the electrode response comprises only A-ionophore can be represented as:

$$
\begin{gathered}
{\left[\mathrm{Fe}^{3+}\right]_{s}=\left[\mathrm{Fe}^{3+}\right]_{m}} \\
{\left[\mathrm{Fe}^{3+}\right]_{m}+\mathrm{A}_{m}=\left[\mathrm{Fe}^{3+}-\mathrm{A}\right]_{m}^{3+}} \\
\Delta E=E_{m}-E_{s}=(R T / F) \ln \left\{k_{i} a \mathrm{Fe}^{3+}\left[1+K_{f}(\text { carrier })\right] /(\text { sites })\right\}
\end{gathered}
$$

where: $m$ refers to the membrane site, and $s$ refers to the solution site. When the membrane comprises both A and $\mathrm{B}$ the mechanism follow the scheme below:

$$
\begin{gathered}
{\left[\mathrm{Fe}^{3+}\left(\mathrm{H}_{2} \mathrm{O}_{2}\right)_{6}\right]^{3+}+\mathrm{A}=\left[\mathrm{Fe}^{3+}-\mathrm{A}\right]^{3+}+6 \mathrm{H}_{2} \mathrm{O}} \\
{\left[\mathrm{Fe}^{3+}-\mathrm{A}\right]^{3+}+\mathrm{B}=\left[\mathrm{Fe}^{3+}-\mathrm{A}\right]^{3+}\left[\mathrm{B}^{-}\right]_{3} .}
\end{gathered}
$$

Response time was estimated according to IUPAC definition [12]. It is the time between the instant when the electrode was brought into contact with sample solution and the first instant when emf/time slope becomes equal to the limiting value selected on the basis of experimental conditions. Dynamic response of the proposed electrode is shown in "Figure 3". From the figure it is shown that response time is between $5-10 \mathrm{~s}$ for the measured concentrations between $10^{-2}-10^{-4} \mathrm{M}$.

\section{2. pH-Effect}

The potential changes versus different $\mathrm{pH}$-values for the three kinds of the membranes were studied. It can be detected that the acidic part differs for type III electrode than others (types I and II). The break at this part occurs at $\mathrm{pH}$ values 3.6, 3.9 and 4.5 to 7 for I, II and III electrodes, respectively. The sensitivity of penta-thiophosphorylatedcalix[6]arene (A) towards the $\mathrm{H}^{+}$is the reason for the absence of the plateau potential in acidic medium for type III membrane electrode. The break in acidic medium is due to the protonation of the corresponding ionophore in the membrane. Under these conditions the iron complex cannot be formed. Representative curves are shown for the proposed iron-ISE with membrane types II and III are shown in "Figure 4" and "Figure 5". 


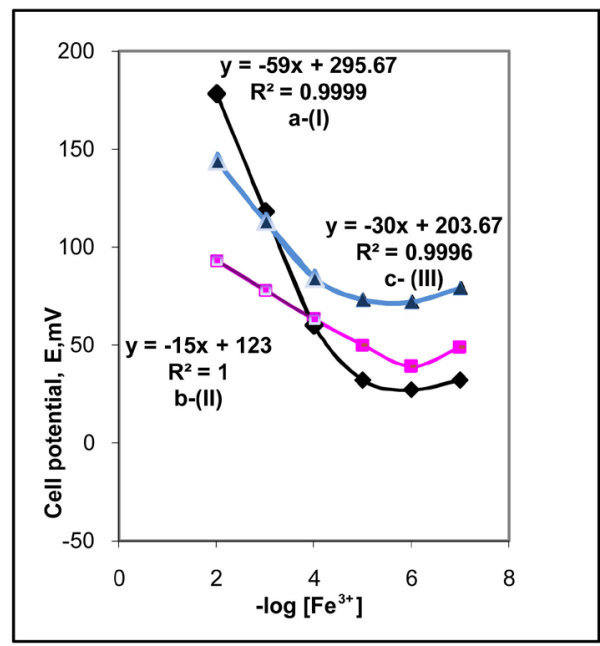

Figure 2. Calibration graphs for iron-ISE comprising: (a) Membrane-I; (b) Membrane-II; (c) Membrane-III.

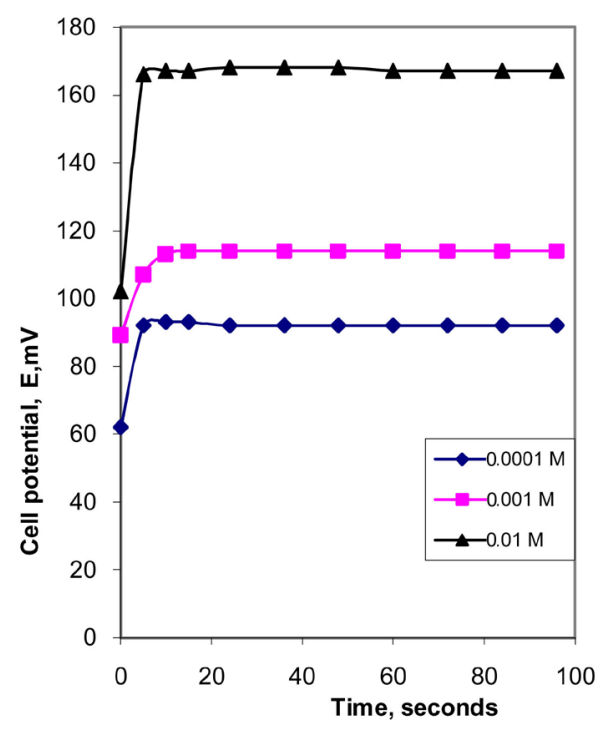

Figure 3. Dynamic response of iron-ISE with membrane type III when measuring $\mathrm{Fe}^{3+}$ solutions with concentrations 0.01, 0.001 , and $0.0001 \mathrm{M}$.

Table 2. Effect of soaking on ferric-ISE-response based on TpClPB ionophore comprising either DOS/or NPOE.

\begin{tabular}{|c|c|c|c|c|c|c|c|c|c|c|c|c|}
\hline \multirow{2}{*}{$\begin{array}{l}\text { Soaking } \\
\text { time }\end{array}$} & \multicolumn{4}{|c|}{ I } & \multicolumn{4}{|c|}{ II } & \multicolumn{4}{|c|}{ III } \\
\hline & Slope & $\mathbf{R}^{2 b}$ & $\mathbf{L R}^{\mathrm{a}}, \mathbf{M}$ & DL, $\mathbf{M}$ & Slope & $\mathbf{R}^{2 b}$ & $\mathbf{L R}^{\mathrm{a}}, \mathbf{M}$ & DL, $\mathbf{M}$ & Slope & $\mathbf{R}^{2 \mathbf{b}}$ & $\mathbf{L R}^{\mathrm{a}}, \mathbf{M}$ & DL, M \\
\hline 1 day & 59 & 0.999 & $10^{-2}-2.5 \times 10^{-5}$ & $2.0 \times 10^{-5}$ & 15 & 1 & $10^{-2}-1.5 \times 10^{-5}$ & $3.1 \times 10^{-7}$ & 30 & 0.999 & $10^{-2}-2.5 \times 10^{-5}$ & $1.2 \times 10^{-5}$ \\
\hline 6 days & 48 & 1 & $10^{-2}-2.5 \times 10^{-5}$ & $1.5 \times 10^{-5}$ & 32 & 1 & $10^{-2}-1.5 \times 10^{-5}$ & $6.3 \times 10^{-6}$ & 22 & 0.993 & $10^{-2}-3.9 \times 10^{-5}$ & $1.2 \times 10^{-5}$ \\
\hline 8 days & 38.5 & 0.948 & $10^{-2}-2.5 \times 10^{-6}$ & $10^{-6}$ & 39 & 0.999 & $10^{-2}-2.5 \times 10^{-5}$ & $1 \times 10^{-5}$ & 24 & 1 & $10^{-2}-2.5 \times 10^{-5}$ & $5.0 \times 10^{-6}$ \\
\hline 42 days & 36.5 & 0.9895 & $10^{-2}-1.5 \times 10^{-6}$ & $6.3 \times 10^{-7}$ & 32 & 0.9987 & $10^{-2}-1.0 \times 10^{-5}$ & $2.5 \times 10^{-6}$ & 25 & 0.9586 & $10^{-2}-2.5 \times 10^{-5}$ & $5.0 \times 10^{-6}$ \\
\hline months & 39 & 0.992 & $10^{-2}-1 \times 10^{-5}$ & $3.9 \times 10^{-6}$ & 47 & 0.999 & $10^{-2}-6.3 \times 10^{-5}$ & $1.5 \times 10^{-5}$ & 25.5 & 0.999 & $10^{-2}-3.9 \times 10^{-5}$ & $3.9 \times 10^{-6}$ \\
\hline
\end{tabular}

${ }^{\mathrm{a}}$ Linear range. ${ }^{\mathrm{b}}$ Correlation coefficient.

It is observed that the plateau potential is more flat for the electrode with membrane type II than in membrane type III. This is expected due to the absence of (B) in the membrane type III. 


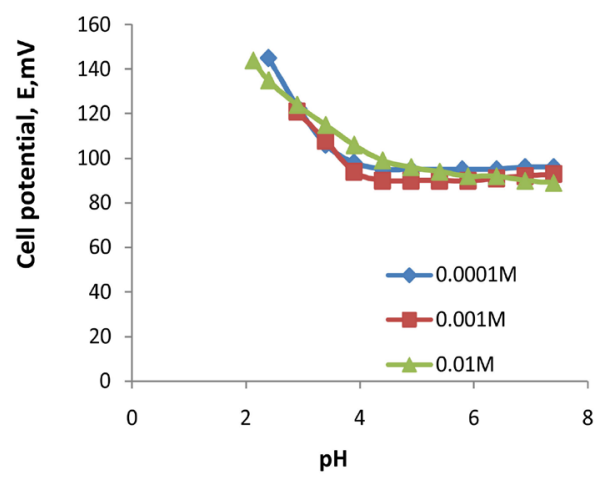

Figure 4. pH-effect on potential of iron-ISE with membrane type II when measuring $\mathrm{Fe}^{3+}$ solutions with concentrations 0.01, 0.001 , and $0.0001 \mathrm{M}$.

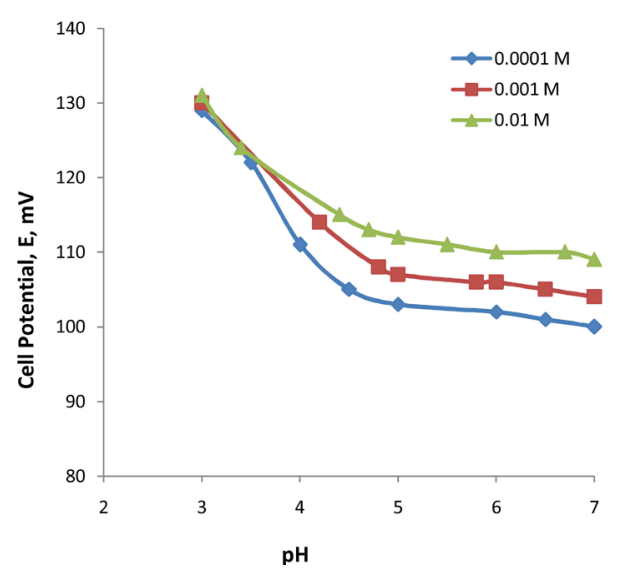

Figure 5. pH-effect on potential of iron-ISE with membrane type III when measuring $\mathrm{Fe}^{3+}$ solutions with concentrations 0.01 , 0.001 , and $0.0001 \mathrm{M}$.

\subsection{Selectivity Properties}

The selectivity of Fe-ISE with different membrane types I, II and III were calculated according to the SSM [12]. "Table 3" shows the obtained $\mathrm{K}_{\mathrm{Fe}^{3+}, \mathrm{x}^{Z_{+}}}^{\mathrm{Pot}}$-values of the selectivity coefficient. It can be reported that most of the tested interferents for Fe-ISE type I shows suitable selectivity. The values of the selectivity coefficients for the ISE-Fe type I towards the tested divalent cations were between $\left(1.03 \times 10^{-2}-5.93 \times 10^{-4}\right)$. For $\mathrm{Hg}^{2+}$, good $\mathrm{K}_{\mathrm{Fe}^{3+}, \mathrm{X}^{Z+}}^{\mathrm{Pot}}$ value was found $\left(5.9 \times 10^{-4}\right)$. Monovalent cations showed $\mathrm{K}_{\mathrm{Fe}^{3+}, \mathrm{X}^{Z_{+}}}^{\mathrm{Pot}}$-values in the range of $(1.1 \times$ $10^{-1}-3.1 \times 10^{-1}$ ), which are relatively higher than the tested divalent cations.

In case of Fe-ISE type II, most of the tested cations showed $\mathrm{K}_{\mathrm{Fe}^{3+}, \mathrm{x}^{\mathrm{P}_{+}}}^{\mathrm{P}}$-values of the order of $\approx 10^{-3}$. This means that the electrode can be applied for measurements in their presence. Monovalent cations like $\mathrm{NH}^{4+}$ exhibits $\mathrm{K}_{\mathrm{Fe}^{3+}, \mathrm{X}^{\mathrm{Z}_{+}}}^{\mathrm{Pot}}$-value of order of $10^{-2}$, while $\mathrm{Na}^{+}$and $\mathrm{Ag}^{+}$showed $\mathrm{K}_{\mathrm{Fe}^{3+}, \mathrm{X}^{\mathrm{Z}_{+}}}^{\mathrm{Pot}}$-value of order $10^{-1}$.

It can be concluded that the type of plasticizer affects the selectivity properties of the electrodes.

When Fe-ISE type III that contains only A/NPOE without $\mathrm{B}$, improvements of $\mathrm{K}_{\mathrm{Fe}^{3+}, \mathrm{x}^{Z+}}^{\mathrm{Pot}}$-values were observed for the most divalents and monovalent cations, except for $\mathrm{Ag}^{+}$, compared to other electrodes (I and II).

The relation between ionic radius of interferent cations and the values of selectivity coefficient is shown in "Figure 6". It is found that the relation has a maximum $\mathrm{K}_{\mathrm{Fe}^{3+}, \mathrm{x}^{\mathrm{Z}_{+}}}^{\mathrm{Pot}^{+}}$-value $(0.237)$ at ionic radius $129 \mathrm{pm}$ (for $\left.\mathrm{Ag}^{+}\right)$for the electrode type III in the three concentrations $(0.01,0.001$, and $0.0001 \mathrm{M})$ [15]. Less values were ob- 
served either when ionic radius is less or more than $129 \mathrm{pm}$. This can be explained due to that $\mathrm{Ag}^{+}$fits the ionophore cavity, which results in highest interaction. The same behavior was proved for the Fe-ISE with membrane types I and II. The highest $\mathrm{K}_{\mathrm{Fe}^{3+}, \mathrm{X}^{\mathrm{Z}}}^{\mathrm{Pot}}$-value was observed for $\mathrm{Ag}^{+}$. "Figure 7" shows the variations of $\mathrm{K}_{\mathrm{Fe}^{3+}, \mathrm{X}^{Z+}}^{\mathrm{Pot}}$-values according to the ionic radius of the tested cations at different concentrations.

\subsection{Application of Fe-ISE for Determining Iron in Actual-Like Samples}

Ten iron-containing samples were analysed for iron by using the proposed electrode "Fe-ISE". The procedure was based on the standard addition method. Most of the obtained results were between 0.02 and $0.078 \mathrm{ppm}$. Only samples 8 and 9 were much higher $(0.12$ and $0.37 \mathrm{ppm})$. The obtained results agreed with those obtained from a spectrophotometric method based on 1,10-phenanthroline according to previously discussed procedures [13]. "Table 4", shows the obtained results for analysis by using both the proposed electrode and the spectrophotmetric methods.

Table 3. Selectivity coefficient values for iron electrodes based on (A + B/NPOE) [I], (A + B/DOS) [II], (A/NPOE) [III] membranes, when measuring $0.001 \mathrm{M}$ ferric/interferent solution.

\begin{tabular}{|c|c|c|c|c|}
\hline \multirow{2}{*}{ Interferent } & \multirow{2}{*}{ Ionic radius } & \multicolumn{3}{|c|}{$\mathrm{K}_{\mathrm{Fe}^{3+}, \mathrm{X}^{2+}}^{\mathrm{Pot}}$} \\
\hline & & I & II & III \\
\hline $\mathrm{Ca}^{2+}$ & 114 & 0.003162 & 0.004084 & 0.001468 \\
\hline $\mathrm{Cd}^{2+}$ & 109 & 0.00194 & 0.005995 & 0.001468 \\
\hline $\mathrm{Ba}^{2+}$ & 149 & 0.016518 & 0.008424 & 0.004338 \\
\hline $\mathrm{Sr}^{2+}$ & 132 & 0.018588 & 0.010248 & 0.004338 \\
\hline $\mathrm{Cu}^{2+}$ & 87 & 0.006571 & 0.005012 & 0.002746 \\
\hline $\mathrm{Mg}^{2+}$ & 86 & 0.011925 & 0.009602 & 0.003314 \\
\hline $\mathrm{Hg}^{2+}$ & 116 & 0.000593 & 0.002154 & 0.000353 \\
\hline $\mathrm{Co}^{2+}$ & 87 & 0.0103 & 0.008389 & 0.005926 \\
\hline $\mathrm{Mn}^{2+}$ & $97-81$ & 0.010926 & 0.008389 & 0.003899 \\
\hline $\mathrm{Pb}^{2+}$ & 133 & 0.001191 & 0.001896 & 0.000947 \\
\hline $\mathrm{NH}_{4}^{+}$ & 175 & 0.182085 & 0.065097 & 0.110069 \\
\hline $\mathrm{Na}^{+}$ & 116 & 0.096895 & 0.112421 & 0.068129 \\
\hline $\mathrm{Ag}^{+}$ & 129 & 0.012276 & 0.310117 & 0.195734 \\
\hline
\end{tabular}

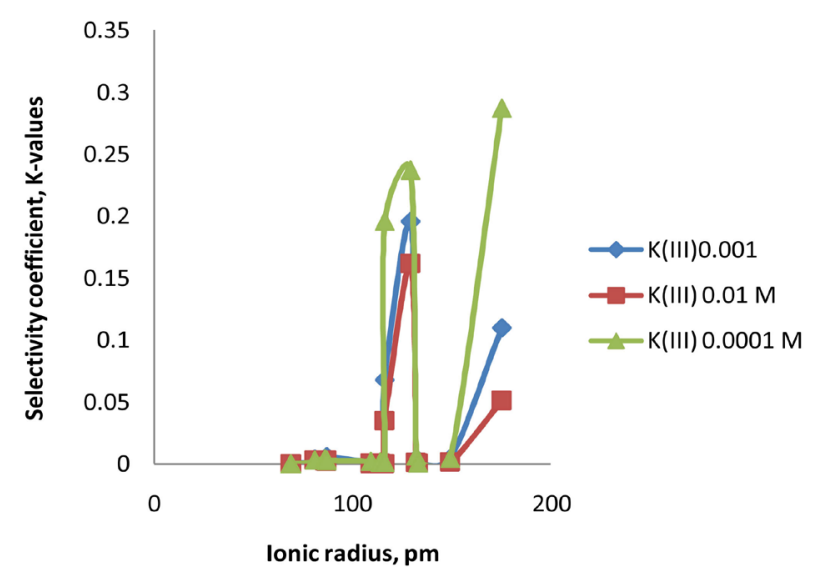

Figure 6. Correlation between ionic radius (pm) of the tested cations and selectivity coefficient $\left(\mathrm{K}_{\mathrm{Fe}^{3+}, \mathrm{x}^{2+}}^{\mathrm{Pot}^{2+}}\right)$ for iron-ISE containing membrane type III for iron solutions with concentrations $0.01,0.001$, and $0.0001 \mathrm{M}$. 


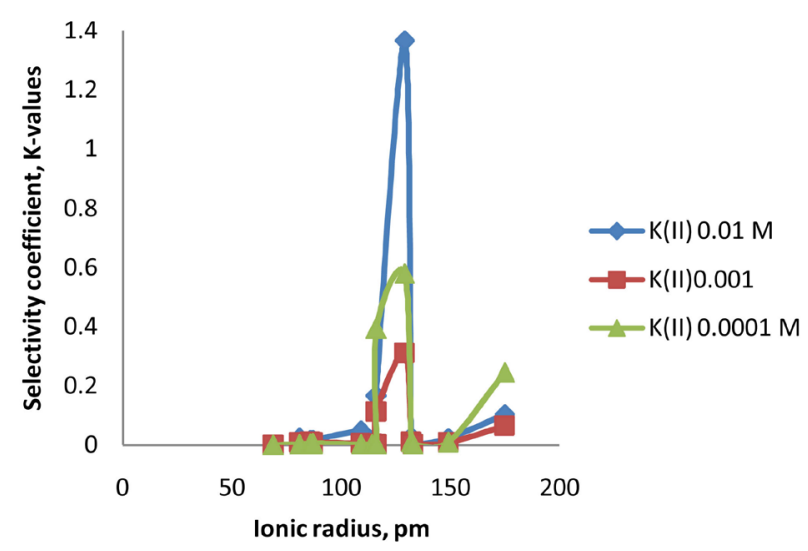

Figure 7. Correlation between ionic radius (pm) of the tested cations and selectivity coefficient $\left(\mathrm{K}_{\mathrm{Fe}^{\mathrm{P}}+\mathrm{x}^{\mathrm{z}+}}^{\mathrm{z}}\right)$ for iron-ISE containing membrane type II for iron solutions with concentrations 0.01, 0.001, and 0.0001 M.

Table 4. Application of iron-ISE for determination of iron in different samples.

\begin{tabular}{ccccc}
\hline \multirow{2}{*}{ No. } & Sample & \multicolumn{2}{c}{$\mathbf{F e}^{\mathbf{3 +}}, \mathbf{p p m}$} & \multirow{2}{*}{ RTD $^{\mathbf{a}}, \mathbf{\%}$} \\
\cline { 3 - 4 } & Sample (1) & Spectrophotometric method & Proposed ISE method & 2.1 \\
2 & Sample (2) & 0.050 & 0.049 & 1.9 \\
3 & Sample (3) & 0.060 & 0.065 & 1.7 \\
4 & Sample (4) & 0.022 & 0.019 & 1.67 \\
5 & Sample (5) & 0.022 & 0.020 & 1.8 \\
6 & Sample (6) & 0.081 & 0.078 & 2.2 \\
7 & Sample (7) & 0.0058 & 0.0057 & 2.13 \\
8 & Sample (8) & 0.058 & 0.052 & 0.95 \\
9 & Sample (9) & 0.120 & 0.120 & 1.1 \\
10 & Sample (10) & 0.360 & 0.370 & 1.5 \\
\hline
\end{tabular}

${ }^{\mathrm{a}}$ Relative standard deviation (4-determinations).

\section{Conclusion}

It can be concluded that iron can be determined by using new sensor based on using new phosphrylated calix-6arene ionophore. The studies of relation between selectivity and ionic radius of interferents recommend that there is a limit for the ionic radius where the selectivity coefficient values reaches maximum. The electrode was applied successfully for analyzing iron in range of $\left(1 \times 10^{-2}-1 \times 10^{-4} \mathrm{M}\right)$. The obtained results agreed with those of a recommended spectrophotometric method [13].

\section{Acknowledgements}

The authors acknowledge Prof. Z. Brzozka, Warsaw Technical Univ, Poland, for providing us with phosphorylated calix-6-derivative.

\section{References}

[1] Zamani, H.A., Anjali, G.M.R., Behmadi, H. and Behnajady, M.A. (2009) Fabrication of an Iron(III) PVC-Membrane Sensor Based on Bis-Benzilthiocarbohydrazide as a Selective Sensing Material. Materials Science and Engineering: $C$, 29, 1535. http://dx.doi.org/10.1016/j.msec.2008.12.004

[2] Zamani, H.A., Hamed-Mosavian, M.T., Hamidfar, E., Ganjali M.R. and Norouzi, P. (2008) A Novel Iron(III)-PVC Membrane Potentiomeric Sensor Based on N-(2-Hydroxyethyl)Ethylenediamine-N,N',N"-Triacetic Acid. Materials Science and Engineering: C, 28, 1551. http://dx.doi.org/10.1016/j.msec.2008.04.013 
[3] Zareh, M.M., Ismail, F.A.I. and Abd Alaziz, M.H. (2010) 1-Pyrrolidine Dicarbodithioate Based Electrodes for Determination of Iron(III) in Lubrication Oil. Electroanalysis, 22, 1369. http://dx.doi.org/10.1002/elan.200900550

[4] Ekmekci, G., Uzun, D., Somer, G. and Kalayc1, Ş. (2007) A Novel Iron(III) Selective Membrane Electrode Based on Benzo-18-Crown-6 Crown Ether and Its Applications. Journal of Membrane Science, 288, 36. http://dx.doi.org/10.1016/j.memsci.2006.10.044

[5] Gupta, V.K., Jain, A.K., Agarwal, S. and Maheshwari, G. (2007) An Iron(III) Ion-Selective Sensor Based on a $\mu$-bis(Tridentate) Ligand. Talanta, 71, 1964. http://dx.doi.org/10.1016/j.talanta.2006.08.038

[6] Sil, A., Ijeri, V.S. and Srivastava, A.K. (2005) Coated-Wire Iron(III) Ion-Selective Electrode Based on Iron Complex of 1,4,8,11-Tetraazacyclotetradecane. Sensors and Actuators B: Chemical, 106, 648. http://dx.doi.org/10.1016/j.snb.2004.09.013

[7] Mashhadizadeh, M.H., Shoaei, I.S. and Monadi, N. (2004) A Novel Ion Selective Membrane Potentiometric Sensor for Direct Determination of Fe(III) in the Presence of Fe(II). Talanta, 64, 1048. http://dx.doi.org/10.1016/j.talanta.2004.05.005

[8] Mahmoud, W.H. (2001) Iron Ion-Selective Electrodes for Direct Potentiometry and Potentiotitrimetry in Pharmaceuticals. Analytica Chimica Acta, 436, 199. http://dx.doi.org/10.1016/S0003-2670(01)00892-3

[9] Hassan, S.S., Mahmoud, W.H. and Othman, A.H. (1998) Ribonucleic Acid as a Novel Ionophore for Potentiometric Membrane Sensors of Some Transition Metal Ions. Talanta, 47, 377. http://dx.doi.org/10.1016/S0039-9140(98)00142-8

[10] Hassan, S.S.M. and Marzouk, S.A.M. (1994) A Novel Ferroin Membrane Sensor for Potentiometric Determination of Iron. Talanta, 41, 891. http://dx.doi.org/10.1016/0039-9140(94)E0042-P

[11] Wroblewski, W. and Brzozka, Z. (1996) Lead versus Cadmium Selectivity of Ion Selective Electrodes Based on Thiophosphorylated Calix[6]Areneionophores. New Journal of Chemistry, 20, 419.

[12] Buck, R.P. and Lindner, E. (1994) Recommendations for Nomenclature of Ionselective Electrodes (IUPAC Recommendations 1994). Pure and Applied Chemistry, 66, 2527. http://dx.doi.org/10.1351/pac199466122527

[13] Eaton, A.D., Clescri, L.S. and Greenberg, A.E. (1995) Standard Methods for Examination of Water and Waste Water. American Public Health Association, Washington DC.

[14] Zareh, M.M. (2009) Blank Membranes versus Ionophore-Based Membranes for the Selective Determination of $\mathrm{H}^{+}$. Analytical Sciences, 25, 1131. http://dx.doi.org/10.2116/analsci.25.1131

[15] Shannon, R.D. (1976) Revised Effective Ionic Radii and Systematic Studies of Interatomic Distances in Halides and Chalcogenides. Acta Crystallographica, A32, 751. http://dx.doi.org/10.1107/S0567739476001551 
Scientific Research Publishing (SCIRP) is one of the largest Open Access journal publishers. It is currently publishing more than 200 open access, online, peer-reviewed journals covering a wide range of academic disciplines. SCIRP serves the worldwide academic communities and contributes to the progress and application of science with its publication.

Other selected journals from SCIRP are listed as below. Submit your manuscript to us via either submit@scirp.org or Online Submission Portal.
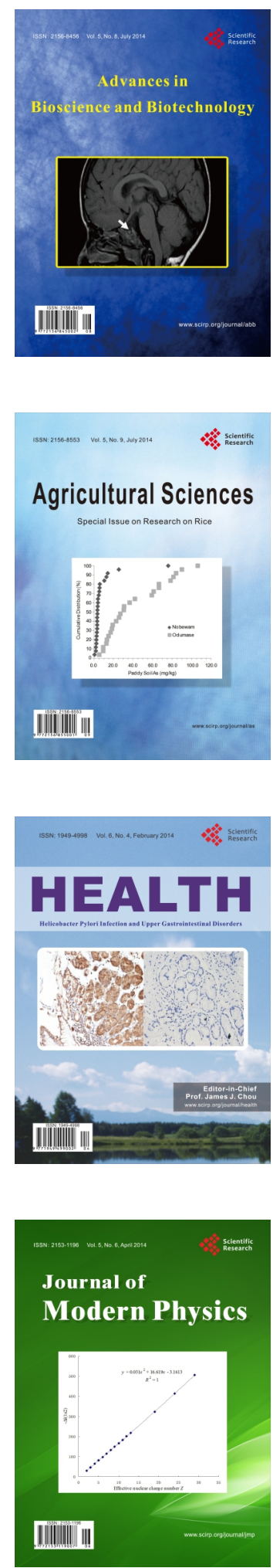
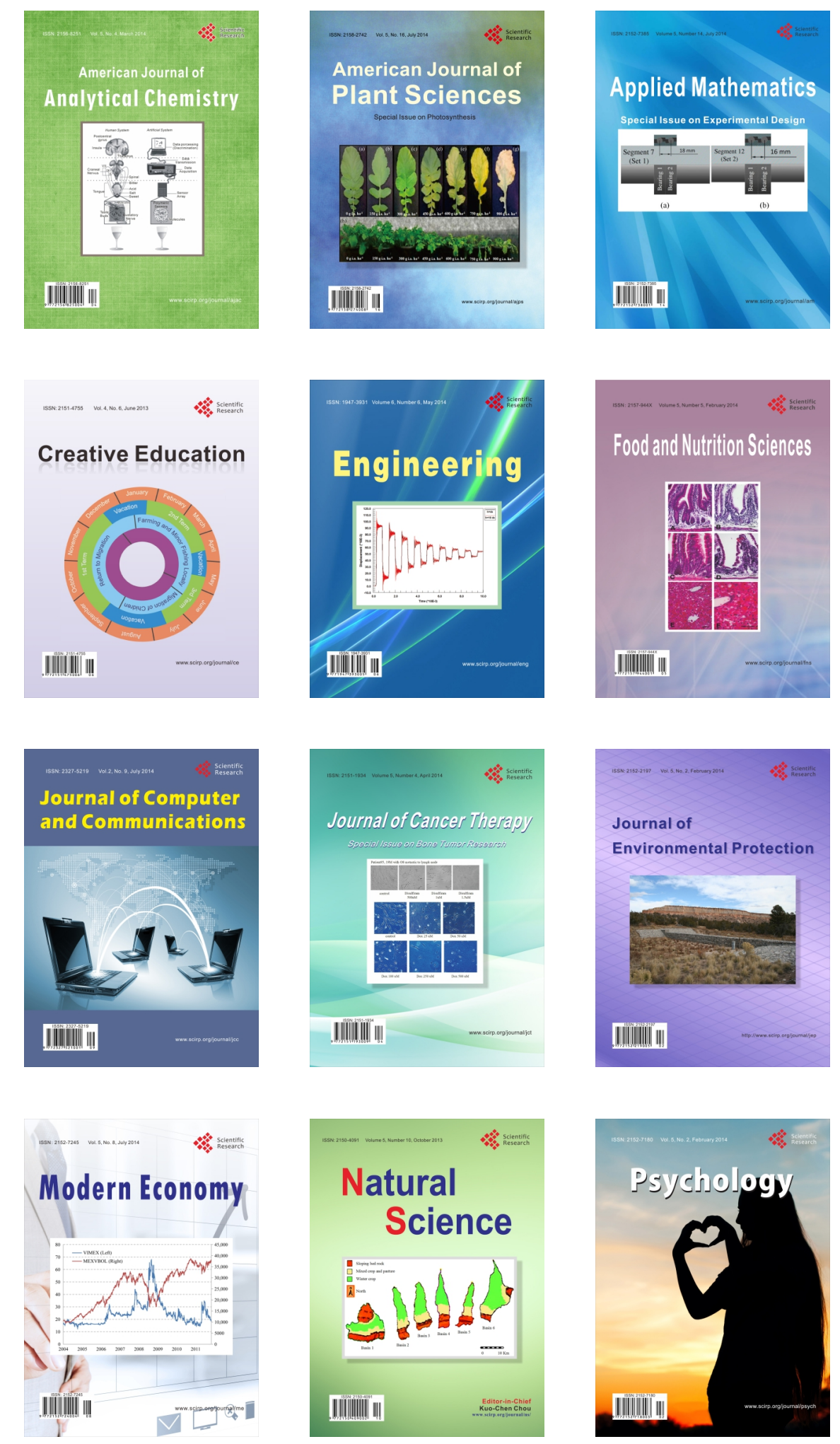